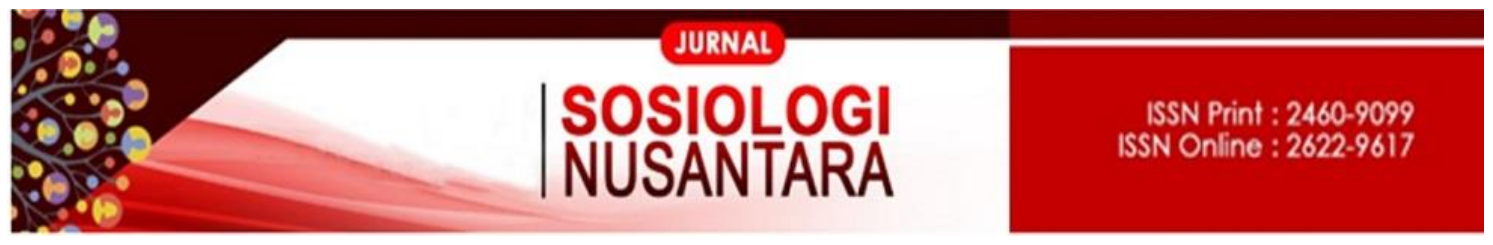

https://ejournal.unib.ac.id/index.php/jsn

DOI ://doi.org/10.33369/jsn.3.1.12-18

\title{
PERAN KELOMPOK USAHA GEROBAK BARANG BEKAS (KUGERBAS) DALAM MEMBANGUN SOLIDARITAS ANGGOTA : (Studi Kasus di Kelurahan Jalan Gedang, Kecamatan Gading Cempaka, Kota Bengkulu)
}

\section{THE ROLE OF THE SCAVENGER BUSINESS GROUP IN THE BUILDING SOLIDARITY OF MEMBERS \\ (Case study in the Urban Village of Jalan Gedang, Sub-District of Gading Cempaka, Bengkulu City)}

\author{
Liyah Syari Khalifah1, Hajar G. Pramudyasmono², Asep Topan ${ }^{3}$ \\ hajargp@unib.ac.id \\ 123. Fakultas Ilmu Sosial dan Ilmu Politik, Universitas Bengkulu
}

\begin{abstract}
Abstrak
Penelitian ini bertujuan untuk mendeskripsikan peran kelompok usaha gerobak barang bekas (Kugerbas) sebagai pengorganisir usaha gerobak barang bekas yang dijalankan anggota Kugerbas. Penelitian ini dilakukan di Kelurahan Jalan gedang, Kecamatan Gading Cempaka, karena Kugerbas di wilayah ini merupakan perintis terbentuknya Kugerbas di Kota Bengkulu dan daerah tersebut merupakan sekretariat Kugerbas. Kugerbas memiliki peran kelompok dengan kegiatan-kegiatan seperti simpan pinjam, arisan, pengajian, gotong royong dalam membangun solidaritas anggota dan untuk membantu anggota dalam meningkatkan status sosial dalam masyarakat atau menghilangkan pandangan negatif masyarakat terhadap para pengumpul barang bekas, terutama para anggota Kugerbas, serta dalam meningkatkan ekonomi anggota.

Pemilihan informan dilakukan berdasarkan teknik purposive sampling. Informan penelitian ini adalah pengurus sekaligus pendiri kelompok usaha gerobak barang bekas dan anggota Kugerbas berjumlah sembilan orang. Masing-masing anggota Kugerbas tinggal dalam satu wilayah, di Gang Rawa Indah, sehingga dalam menyimpan atau menyortir barang bekas, mereka kumpulkan dalam satu tempat penyimpanan, yang mereka sebut gudang bersama. Data dikumpulkan melalui observasi, wawancara mendalam dan dokumentasi, yang telah dilaksanakan kurang lebih selama satu tahun. Kugerbas merupakan jenis Kelompok dengan Solidaritas Mekanik, tetapi temuan di lapangan Kugerbas juga merupakan kelompok dengan Solidaritas Organik, jadi kelompok tersebut merupakan kelompok dengan istilah Kuasi Organik (Soldaritas Organik semu) karena mereka merupakan kelompok Jenis Solidaritas Mekanik yang memiliki kesadaran Kolektif, akan tetapi mereka juga menggunakan Struktur atau Solidaritas Organik sebagai formalitas kelompok untuk mendapat pengakuan sebagai organisasi. Peran Kugerbas dalam meningkatkan status
\end{abstract}


sosial anggota dan membangun solidaritas anggota adalah dengan memperhatikan kohesi/persatuan pada kelompok, motif atau dorongan anggota untuk tetap bertahan dalam kelompok, struktur keanggotaan Kugerbas, kepemimpinan dalam kelompok serta perkembangan kelompok usaha gerobak barang bekas.

Kata Kunci: Peran Kelompok, Kelompok Usaha Gerobak Barang Bekas(KUGERBAS), Solidaritas Sosial

\section{Abstract}

This study aims to describe the role of Kugerbas as the organizer of scavenger business by members of Kugerbas. This research was conducted in the urban Village of Jalan Gedang, Sub-district of Gading Cempaka, Bengkulu City, because Kugerbas urban Village of Jalan Gedang is a pioneer of Kugerbas in Bengkulu City and the area is Kugerbas secretariat. Kugerbas has a group role with activities such as savings and loans, social gathering, recitals, team work in building member solidarity and to assist members in improving social status in society or eliminate negative views of society to collectors, especially members of Kugerbas, and in Improve member economies.

Selection of informants was done based on purposive sampling technique. The informant of this research is the board and founder of business group of scavenger business and members of Kugerbas Urban Village of Jalan Gedang which amounted to nine people. Each member of Kugerbas lives in one area, in Gang Rawa Indah, so in storing or sorting used goods, they collect it in one storage area, which they call a warehouse together. Data are collected through observation, in-depth interviews and documentation, which have been implemented for approximately one year. Activity in data analysis that start from data reduction, data presentation and withdrawal of conclusion. This study uses the functional structural theory of the social fact paradigm. Kugerbas is a type of group with mechanical solidarity, but the findings in the research of Kugerbas are also groups with organic solidarity, so the group with the term organic quasi (organic solidarity false), because they are groups of mechanical solidarity that have collective awareness, using structure or the organic solidarity as a formality group to gain recognition as an organization. The role of Kugerbas in improving members 'social status and building members' solidarity is to pay attention to the group's cohesion, motivation or encouragement to stay in groups, membership structure of Kugerbas, group leadership and the development of scavenger business group.

Keywords: Role Of a Group, A Business Group Used Goods Wagon (KUGERBAS), SocialSolidarity.

\section{PENDAHULUAN}

Kehidupan manusia tidak dapat dipisahkan dari lingkungan, baik lingkungan alam maupun lingkungan sosial. Soemarwoto(2001:53) mengatakan bahwa lingkungan adalah jumlah semua benda dan kondisi yang ada dalam ruang yang ditempati yang mempengaruhi kehidupan. Volume sampah di Kota Bengkulu berjumlah 877.70 m3/hari. Salah satu program yang dilakukan oleh pemerintahIndonesia dalam memberikan apresiasi mendalam bagi penggiat gagasan terciptanya masyarakat sejahtera melalui PNPM-P2KP (Program Nasional Pemberdayaan Masyarakat- 
Program Peningkatan Kualitas Pemukiman). PNPM-P2KP memfasilitasi kelompokkelompok yang dibentuk berdasarkan wilayah perkecamatan yang dinamakan BKM (Badan Keswadayaan Masyarakat).

Salah satu diantaranya berada di Kelurahan Jalan Gedang, Kecamatan Gading Cempaka, Kota Bengkulu. BKM membagi kelompok lagi menjadi KSM (Kelompok Swadaya Masyarakat). Salah satu KSM yang terdapat di Kelurahan Jalan Gedang adalah KSM Kugerbas (Kelompok Usaha Gerobak dan Pengumpul Barang Bekas). KSM Kugerbas adalah sebuah kelompok yang menaungi masyarakat yang berpotensi sebagai pengumpul barang bekas dengan menggunakan gerobak. Kugerbas terbentuk pada November 2010 dan awal berdirinya kelompok beranggotakan 22 orang pemulung. Pemulung yang telah bergabung dalam Kugerbas mendapatkan fasilitas gerobak yang bagus. Gerobak tersebut memiliki nomor gerobak dan juga tertera nomor telepon, serta status anggota yang terorganisir, sehingga pandangan masyarakat terhadap pemulung menjadi lebih positif, akibatnya pemulung lebih bebas bergerak mencari rezeki.

Seiring berjalannya waktu, pekerjaan mereka tidak hanya mencari barang bekas, ada yang membantu masyarakat pindah rumah, memotong rumput dan membuang sampah. Penulis akan melakukan penelitian bagaimana peran kelompok dalam membangun solidaritas sosial anggota kelompok. Penelitian tentang solidaritas kelompok pernah dilakukan oleh Utami (2015), yang memfokuskan penelitiannya pada solidaritas kelompok waria di Kota Bengkulu. Penelitian selanjutnya dilakukan oleh Yuslindawati (2015) yang memfokuskan pada solidaritas masyarakat Pasemah dalam tradisi pantauan (mangkalluae) di Kedurang, sedangkan fokus penelitian ini yaitu bagaimana peran Kugerbas dalam membangun solidaritas anggota. Dengan tujuan penelitian untuk memperoleh gambaran atau mendeskripsikan peran Kugerbas dalam membangun solidaritas anggota. Penelitian ini menggunakan teori struktural fungsional dengan paradigma fakta sosial.

\section{METODE PENELITIAN}

Penelitian ini menggunakan metode penelitian kualitatif dan dilakukan di Kelurahan Jalan Gedang Kecamatan Gading Cempaka, Kota Bengkulu. Lokasi tersebut dipilih karena Kugerbas Jalan Gedang merupakan perintis terbentuknya dan sekretariat 
kelompok Kugerbas di Kota Bengkulu. Informan yang diambil dalam penelitian ini sebanyak 8 orang anggota Kugerbas termasuk 1 orang yang merupakan pendiri Kugerbas. Teknik pengumpulan data yang dilakukan adalah dengan observasi (pengamatan), wawancara, serta dokumentasi. Teknik analisa data menggunakan tiga teknik yaitu reduksi data, penyajian data dan penarikan kesimpulan.

\section{PEMBAHASAN}

\section{Kelompok Usaha Gerobak Barang Bekas (Kugerbas) Kelurahan Jalan Gedang}

\section{Gambaran Kugerbas}

Pada gambaran Kugerbas akan dibahas tentang nilai ekonomis barang bekas, usaha dibidang gerobak barang bekas, terbentuknya kelompok Kugerbas dan struktur kepengurusan serta visi dan misi Kugerbas.

\section{a. Barang Bekas}

Pemulung adalah seseorang yang bekerja mengumpulkan barang-barang bekas, dengan cara mencari ditempat pembuangan sampah atau dirumah-rumah, tempat umum dan kantor-kantor, sebagian pemulung mengumpulkan atau memilah barang yang dianggap berguna dari masyarakat yang ingin menjual barang-barang yang telah rusak.

\section{b. Usaha Gerobak Barang Bekas}

Barang bekas yang dianggap tidak berguna oleh masyarakat ternyata dapat membantu kehidupan para pemulung. Barang-barang yang sudah tidak terpakai atau sudah rusak memiliki nilai jual. Seseorang yang dapat melihat nilai tersebut salah satunya adalah pemulung. Mereka yang dulunya hanya mencari barang bekas dari tempat pembuangan sampah atau truk-truk sampah yang akan bongkar muatan, setelah mereka melihat nilai jual yang cukup menguntungkan, mereka membuat usaha barang bekas, mereka mulai membeli barang-barang bekas dari masyarakat, atau sampahsampah kertas dan barang elektronik yang sudah rusak dari kantor-kantor, dan ada juga yang hanya membeli atau mengumpulkan barang-barang tertentu saja, mereka hanya membeli barang-barang jenis kardus-kardus bekas, buku-buku, majalah dan jenis kertas lainnya, ada yang hanya membeli.

\section{c. Kelompok Usaha Gerobak Barang Bekas}

Salah satu program yang dilakukan oleh pemerintah adalah memberikan apresiasi yang mendalam bagi penggiat gagasan terciptanya masyarakat sejahtera 
melalui PNPM-P2KP (Program Nasional Pemberdayaan Masyarakat-Program Peningkatan Kualitas Pemukiman). KSM Kugerbas adalah sebuah kelompok yang menaungi masyarakat yang berpotensi sebagai pengumpul barang bekas dengan menggunakan gerobak.

\section{Keanggotaan Kugerbas}

Anggota kelompok awal dibentuknya Kugerbas berjumlah 22 orang, mereka tinggal berdekatan di Gang Rawa Indah, Kelurahan Jalan Gedang. Bapak Ed merupakan anggota yang telah bergabung selama kurang lebih enam tahun, bapak Ed bergabung dengan Kugerbas setelah enam bulan terbentuknya, setelah melihat perubahan yang terjadi pada temannya, setelah ajakan temannya, ia bergabung dengan Kugerbas. Bapak Ms merasa para pemulung telah membantu untuk membersihkan lingkungan dari sampah yang sulit diuraikan oleh tanah, dan melihat barang tersebut sebagai barang yang memiliki nilai jual. Bapak Ms yang tidak bekerja sebagai pemulung bersedia menjadi ketua Kugerbas, selain ia dipercaya oleh para anggota, ia tidak terlalu disibukkan dengan pekerjaan, jadi dianggap oleh anggota bisa mengurus kelompok dengan baik. Karena bapak Ms juga adalah orang yang berpendidikan, ketika ada bantuan atau kegiatan yang dilakukan oleh pemerintah setempat bapak Ms lah yang mengurusnya.

\section{Struktur Kepengurusan Kugerbas}

Struktur kepengurusan Kugerbas terdiri dari ketua, bendahara, sekertaris, kepala bidang dan anggota, kepengurusan atau struktur ini dibentuk untuk memudahkan anggota dalam mengurus administrasi keanggotaan, dan saat akan ada kegiatan mereka menjalankan tugas mereka masing masing. Ketua menjalin kerja sama dengan pemerintahan atau organisasi lainnya, mengatur jalannya organisasi.

\section{Membangun Solidaritas Anggota}

\section{Peran Kugerbas}

Kugerbas di Kelurahan Jalan Gedang dipelopori oleh Bapak Mardan Siregar pada November 2010. Awal berdirinya Kugerbas hanya beranggotakan 22 orang pemulung yang tinggal di Gang Rawa Indah RT 05 RW 02 Kelurahan Jalan Gedang Kecamatan Gading Cempaka Kota Bengkulu. Pada September 2011 kelompok ini mendapat dukungan dari PNPM- P2KP yaitu berupa bantuan ekonomi bergulir secara bertahap sebesar 3 juta rupiah masing-masing kepada 12 kepala keluarga (12orang) 
anggota Kugerbas dan berikutnya 11 kepala keluarga dan 20 kepala keluarga, dengan demikian mereka memiliki modal usaha untuk membeli atau menampung barang bekas untuk kemudian mereka jual kepada penampung besar atau pemilik gudang barang bekas. Karena semakin banyak anggota, dan kepercayaan yang telah terbangun dikalangan masyarakat, pekerjaan mereka tidak hanya mengumpulkan barang bekas namun ada aktivitas lain yang mereka kerjakan, antara lain membantu masyarakat pindah rumah, memotong rumput, membuang sampah dan para pengumpul barang bekas ini mendapatkan kepercayaan dari masyarakat.

\section{Solidaritas Sosial Kugerbas}

Kondisi Kugerbas yang baik dapat dilihat dari interaksi yang terjalin antara anggota dalam kelompok tersebut, sesuatu yang terjadi pada Kugerbas mulai dari arus informasi serta pertukaran-pertukaran pengaruh antar sesama anggota kelompok, yang ditentukan oleh ketua kelompok yang nantinya dapat mencapai tujuan yang ditentukan serta menguntungkan bagi anggota.

\section{KESIMPULAN}

Hasil penelitian menunjukkan bahwa Kugerbas membawa pengaruh yang positif bagi para anggota, baik dari tingkat pendapatan maupun status sosial para anggota. Perolehan pendapatan mereka ternyata ada perbedaan atau peningkatan yang terlihat sebelum dan sesudah mereka menjadi anggota kelompok, sebelum mereka bergabung pendapatan mereka hanya sekitar 50.000/hari dan meningkat menjadi kurang lebih 100.000/hari setelah mereka menjadi anggota Kugerbas. Status sosial mereka dalam masyarakat sekitar juga menjadi lebih baik, anggapan negatif tentang pemulung berubah setelah mereka bergabung dengan anggota Kugerbas. Terkait dengan teori struktural fungsional yang dipaparkan Talcot Parson mengenai struktur fungsional yaitu adaptasi, pencapaian tujuan, integrasi, dan latensi.

Kugerbas dapat terbentuk berdasarkan dari hubungan yang bersifat homogen ataupun rasa kekeluargaan karena tinggal pada satu wilayah yang saling bertetangga. Pertama, kohesi/persatuan kelompok yaitu ketertarikan pada keanggotaan kelompok dari setiap anggota kelompok yang dapat mempengaruhi anggota kelompok dalam bertahan di dalam Kugerbas. Kedua, motif/dorongan yaitu tujuan bersama anggota kelompok yang satu dan lainnya memiliki landasan bersama ketika mereka bergabung, 
dan motif yang membuat mereka bergabung kedalam Kugerbas, salah satunya adalah ketika mereka bergabung kedalam kelompok pendapatan mereka akan bertambah, dikarenakan dalam melakukan pekerjaan sehari-hari mereka mendapat kepercayaan dari masyarakat.

Ketiga, struktur kelompok dari Kugerbas merupakan jenis kelompok solidaritas mekanik, jadi meskipun adanya struktur kepengurusan dalam kelompok, mereka akan tetap bisa melaksanakan pekerjaan serta menjalankan aktifitas mereka tanpa bantuan anggota lain, tetapi mereka tetap memperhatikan kerjasama dalam kelompok. Keempat, kepemimpinan yakni kelompok Kugerbas mengambil keputusan bukan hanya dari keputusan seorang ketua, tetapi diambil secara musyawarah dan ketua akan memutuskan hasil yang telah dimufakati. Terakhir, perkembangan kelompok dari Kugerbas belum terlihat pesat, tetapi beberapa perubahan dan perkembangan sudah dirasakan oleh anggota. Perkembangan kelompok dapat pula menentukan kehidupan kelompok yang terlihat pada perubahan dalam kelompok, susah senangnya menjadi bagian dari Kugerbas, maupun persatuan dan perpecahan yang terjadi.

Saran yang dapat diberikan berdasarkan hasil penelitian adalah: kepengurusan dalam Kugerbas yang merupakan kelompok solidaritas mekanik memang tetap bisa berjalan meskipun ada peran yang tidak terlaksana, tetapi tetap perlu adanya tanggung jawab pengurus untuk mengkoordinasi anggotanya. Perlunya melakukan pertemuan rutin atau musyawarah kelompok yang membahas tentang kelompok, sehingga kebersamaan dan kekompakan anggota semakin kuat demi tercapainya kelompok yang lebih baik. Masyarakat ikut berpartisipasi dalam memilah sampah yang dapat di daur ulang dan yang tidak sehingga lingkungan masyarakat menjadi bersih dan terhidar dari penyakit yang dapat ditimbulkan tumpukan barang bekas. Pemerintah kelompok Kugerbas terutama dari Dinas Kesejahteraan.

\section{DAFTAR PUSTAKA}

Soemarwoto, Otto.2001. Pengelolaan Lingkungan Hidup. Yogyakarta: University Press.

Utami, Wani Sri. 2015. Solidaritas Kelompok Waria. Skripsi. Bengkulu: Universitas Bengkulu.

Yuslindawati. 2015. Solidaritas Masyarakat Pasemah dalam Tradisi Pantauan (Mangkal Luae) di Kedurang. Skripsi. Bengkulu: Universitas Bengkulu. 